\title{
UPAYA PENGEMBANGAN AGRIBISNIS PADI (ORYZA SATIVA L.) DI KABUPATEN INDRAMAYU
}

\section{Wiwik Ambarsari ${ }^{1}$, Vitus Dwi Yunianto Budi Ismadi ${ }^{2}$, dan Agus Setiadi ${ }^{2}$}

1)Tenaga Pengajar Program Studi Agribisnis Fakultas Pertanian Universitas Wiralodra 2)Staf Pengajar Pascasarjana Agribisnis Fakultas Peternakan dan Pertanian Universitas Diponegoro e-mail : 1)wiwikambarsari@yahoo.co.id

\begin{abstract}
This research aims to formulate priority of the alternative strategy of the development rice agribusiness and the alternative strategy priority that can be applied to the development of rice agribusiness in Indramayu Regency. This research was done through a survey approach, using descriptive and qualitative analysis. The sampling was done by multistage purposive sampling to 120 rice farmers, and purposive sampling of 15 key persons, namely experts, policy experts, practitioners, businesses, experienced farmers and related agencies. The analysis method used was the Analytical Hierarchy Process (AHP) method with Expert Choice 9.0 Program. The research was conducted from February to August 2014 in Sliyeg, Lelea, and Gabuswetan Districts, Indramayu Regency. The results of this research were the five alternative priorities as the formula of the development strategy of rice agribusiness in Indramayu Regency were the consistency of local government of rice farming development, assurance and protection of the rice price through the modern village barns, the enhancement of agricultural extension workers quality and quantity, development of modern village barns infrastructures, and capital assistance from the Local Owned Enterprises. The key priority alternative strategy of the development rice agribusiness in Indramayu Regency was the consistency of local goverment of rice farming development.
\end{abstract}

Keywords: rice agribusiness, goverment policy

\section{PENDAHULUAN}

Penduduk di Kabupaten Indramayu pada tahun 2012 berjumlah 1.663.516 jiwa dengan konsumsi beras $120 \mathrm{~kg}$ per kapita per tahun sehingga membutuhkan beras sebanyak 199.621,92 ton, dengan jumlah beras yang dihasilkan 863.681,35 ton (Tabel 1) maka terjadi surplus beras sebanyak $664.059,43$ ton (76,89\% dari total beras Kabupaten Indramayu) yang dikontribusikan untuk Provinsi Jawa Barat dan Nasional sebagai pendapatan asli daerah (PAD) Kabupaten Indramayu.
Pada Tabel 1 terlihat bahwa pendapatan asli daerah komoditas padi Kabupaten Indramayu tahun 2012 di tingkat petani dalam bentuk gabah kering panen (GKP) dengan harga pembelian pemerintah (HPP) sebesar Rp 4.300 diperoleh Rp 6,88 triliun, di tingkat penggilingan dalam bentuk gabah kering giling (GKG) dengan HPP sebesar Rp 4.900 diperoleh $\mathrm{Rp}$ 6,75 triliun, di tingkat pasar dalam bentuk beras dengan HPP sebesar Rp 8.500 diperoleh $\mathrm{Rp} \mathrm{7,34}$ triliun. (Perhitungan HPP berdasarkan Inpres No.3 Tahun 2012 dalam Laporan Tahunan Dinas Pertanian dan Peternakan Kabupaten Indramayu 2013).

Tabel 1. Pendapatan Asli Daerah (PAD) Kabupaten Indramayu dari Produksi Padi dan Beras Tahun 2012 Berdasarkan Harga Pembelian Pemerintah (HPP) Menurut Inpres No.3 Tahun 2012

\begin{tabular}{|l|r|r|r|}
\hline \multicolumn{1}{|c|}{ Uraian } & Produksi (kg) & \multicolumn{1}{c|}{ HPP (Rp) } & \multicolumn{1}{c|}{ PAD (Rp) } \\
\hline GKP Tingkat Petani & $1.599 .403 .510,00$ & $4.300,00$ & $6.877 .435 .093 .000,00$ \\
\hline GKG di Penggilingan & $1.376 .604 .000,00$ & $4.900,00$ & $6.745 .359 .600 .000,00$ \\
\hline Beras & $863.681 .350,00$ & $8.500,00$ & $7.341 .291 .475 .000,00$ \\
\hline
\end{tabular}

Sumber : BPS Jawa Barat Tahun 2013 Diolah Tahun 2014. 
Perkembangan penanaman padi dari tahun ke tahun di Kabupaten Indramayu mengalami penurunan luas panen padi. Tabel 2 memperlihatkan bahwa Kabupaten Indramayu mengalami penurunan luas panen sebesar 20.343 ha $(8,45 \%)$, produktivitas naik sebesar $6,04 \mathrm{ku} / \mathrm{ha}(10,70 \%)$, dan produksi padi mengalami kenaikan sebesar 18.163 ton GKG $(1,34 \%)$ dari tahun 2010 sampai tahun 2012, sedangkan tahun 2012 terjadi penurunan sebesar 38.446 ton GKG (2,72\%) dari tahun 2011. Hal ini menunjukkan adanya kecenderungan penurunan luas panen yang berakibat penurunan hasil padi setiap tahunnya dan ketersediaan beras akan menurun pula. Penurunan hasil padi tentunya menjadi permasalahan yang harus diperhatikan. Alih fungsi lahan pertanian ke lahan non pertanian dapat menjadi salah satu penyebab penurunan produksi padi.

Suherman (2013) menyebutkan bahwa Kabupaten Indramayu mengalami konversi lahan sawah beririgasi ke non pertanian sebesar 0,12 persen per tahun dari total lahan sawah 116.039 hektar dan cenderung meningkat setiap tahunnya karena sejalan dengan perkembangan penduduk dan kebutuhan lahan serta perkembangan perekonomian suatu wilayah.

Penurunan hasil padi dilaporkan pula oleh Dinas Pertanian dan Peternakan Kabupaten Indramayu Tahun 2012 yang disebabkan beberapa kendala, diantaranya : (1) tingkat kehilangan hasil akibat pengolahan pasca panen masih terlalu tinggi, (2) masih tingginya serangan organisme penyakit tanaman utama, (3) bencana alam kebanjiran dan kekeringan yang cukup luas, (4) permodalan yang dimiliki petani masih rendah, (5) teknologi spesifik belum diterapkan secara lengkap dan berkelanjutan, dan (6) marketable surplus yang masih belum tertangani secara nyata sehingga mempengaruhi cara budidaya padi. Hal ini tentunya belum dapat sepenuhnya mewujudkan penyediaan pangan, seperti yang ditekankan pada Peraturan Pemerintah No. 68 Tahun 2002 pada Pasal 2 dengan beberapa upaya untuk mewujudkannya, diantaranya : (1) mengembangkan sistem produksi pangan yang bertumpu pada sumberdaya, kelembagaan, dan budaya lokal, (2) mengembangkan efisiensi sistem usaha pangan, (3) mengembangkan teknologi produksi pangan, (4) mengembangkan sarana dan prasarana produksi pangan, dan (5) mempertahankan dan mengembangkan lahan produktif dalam pemenuhan swasembada pangan. Secara nasional swasembada pangan sudah tercapai pada periode RPJMN (Rencana Pembangunan Jangka Menengah Nasional) tahap ke-1 (20052009) dalam tahapan RPJPN (Rencana Pembangunan Jangka Panjang Nasional) dari tahun 2005-2025 pada UU No.17 Tahun 2007.

Kondisi saat ini, Indonesia memasuki RPJMN tahap ke-2 (2010-2014) untuk mencapai swasembada berkelanjutan dengan program Ketahanan Pangan pada peraturan Menteri Pertanian, No. 15/Permentan/ Rc.110/1/2010 selama lima tahun (2010-2014) yang mencanangkan 4 (empat) target utama pengembangan agribisnis, yaitu : (1) pencapaian swasembada dan swasembada berkelanjutan, (2) peningkatan diversifikasi pangan, (3) peningkatan nilai tambah, daya saing, dan ekspor, serta (4) peningkatan kesejahteraan petani.

Tabel 2. Luas Panen, Produktivitas, Produksi Padi, dan Beras di Kabupaten Indramayu Tahun, 2010, 2011, dan 2012

\begin{tabular}{|c|c|c|c|c|}
\hline Tahun & $\begin{array}{c}\text { Luas Panen } \\
\text { (Ha) }\end{array}$ & $\begin{array}{c}\text { Produktivitas } \\
\text { (Ku/Ha) }\end{array}$ & $\begin{array}{c}\text { Produksi Padi } \\
\text { (Ton GKG) }\end{array}$ & $\begin{array}{c}\text { Beras* } \\
\text { (Ton) }\end{array}$ \\
\hline 2012 & 220.373 & 62,47 & 1.376 .604 & $863.681,35$ \\
\hline 2011 & 230.985 & 61,26 & 1.415 .050 & $887.802,37$ \\
\hline 2010 & 240.716 & 56,43 & 1.358 .441 & $852.285,88$ \\
\hline
\end{tabular}

Sumber : BPS Jawa Barat Tahun 2010 sampai 2012

Keterangan : *Konversi GKG menjadi beras : 62,74\% dalam Laporan Tahunan Dinas Pertanian dan Peternakan Kabupaten Indramayu Tahun 2011. 
Pencapaian swasembada padi berkelanjutan ditargetkan tahun 2014 produksi padi mencapai 75,70 juta ton gabah kering giling (GKG) setara dengan $47.494,180$ ton beras di tingkat nasional. Dinas Pertanian dan Peternakan Kabupaten Indramayu menargetkan tahun 2014 produksi padi sebesar 1.634.829 ton GKG setara dengan $1.025 .528 .232 \mathrm{~kg}$ beras $(1.025,528$ ton beras) dengan luas panen 233.280 ha dan produktivitas $70,08 \mathrm{ku} / \mathrm{ha}$.

Kondisi ini tentunya harus bersinergi dengan pengembangan agribisnis Kementerian Pertanian melalui tujuh gema revitalisasi dan program ketahanan pangan. Gema revitalisasi, yaitu : (1) lahan, (2) pembenihan dan perbibitan, (3) infrastruktur dan sarana, (4) sumber daya manusia, (5) pembiayaan, (6) kelembagaan, dan (7) teknologi dan industri hilir. Program ketahanan pangan selama tahun 2010-2014 bertujuan mengatasi permasalahan yang ada, diantaranya melalui : (1) penerapan Sekolah Lapang Pengelolaan Tanaman Terpadu (SL-PTT), (2) mengantisipasi pengamanan dalam peningkatan Organisme Pengganggu Tanaman (OPT), (3) dampak perubahan iklim (DPI) melalui pengawalan yang ketat, (4) pemberdayaan petugas di lapangan, (5) koordinasi dengan instansi terkait, (6) gerakan pengendalian, (7) peningkatan kewaspadaan, (8) penyiapan sarana dan prasarana, (9) bantuan benih melalui Bantuan Langsung Benih Unggul (BLBU) dan (10) bantuan pupuk melalui Bantuan Langsung Pupuk (BLP). Seperti penelitian Nataprawira (2006) dengan metode penelitian studi kasus, alat bantu pengumpulan data primer menggunakan kuesioner dan alat analisisnya adalah SWOT (Strenghts, Weakness, Opportunity, and Threaths) dan AHP (Analitycal Hierarcy Process). Hasil penelitian ini adalah : (1) Faktor-faktor yang menentukan keberhasilan pengembangan agribisnis padi organik adalah : (a) sumberdaya manusia, (b) sumber daya alam, (c) sarana dan prasarana, (d) pemasaran, (e) permodalan, dan terakhir (f) kebijakan pemerintah. (2) Hasil dari program AHP sebagai strategi yang dipilih adalah (a) pengembangan komoditas padi organik yang siap pasar berdasarkan keunggulan komparatif melalui pendekatan kawasan yang terintegrasi dengan pembangunan pedesaan, (b) melalui pemberdayaan peranan petani dengan meningkatkan kualitas sumber daya manusia petani sehingga mampu mengendalikan sumber daya alam lokal guna perluasan padi organik dan peningkatan pendapatan.

Berdasarkan latar belakang maka diperlukan penelitian yang bertujuan untuk merumuskan formula prioritas alternatif upaya pengembangan agribisnis padi (Oryza sativa, L.) di Kabupaten Indramayu. Rumusan ini dimaksudkan sebagai rekomendasi bagi pemerintah daerah Kabupaten Indaramayu dalam menentukan kebijakan pembangunan pertanian pada komoditas padi sehingga dapat memberikan kontribusi pada program swasembada berkelanjutan.

\section{METODE}

Penelitian ini adalah penelitian deskriptif kuantitatif dan kualitatif melalui metode pendekatan survei (Nazir, 1983). Pengambilan sampel petani padi sebagai responden dilakukan secara multistage purposive sampling berjumlah 120 orang, dimaksudkan sebagai langkah awal penelitian ini untuk melihat permasalahan dan potensi agribisnis padi di Kabupaten Indramayu sebagai acuan untuk kriteria dan alternatif upaya pengembangan agribisnis padi. Purposive sampling berjumlah 15 orang sebagai key person (terpilih berdasarkan pertimbangan), yang berkompetan di bidangnya yaitu ahli sosial ekonomi, ahli kebijakan, praktisi usaha, petani andalan, dan dinas terkait.

Metode pengumpulan data dilakukan secara observasi, wawancara mendalam, dan kuesioner. Metode analisis yang digunakan adalah Analitycal Hierarchy Process (AHP) dengan program Expert Choice 9.0.

Penentuan lokasi penelitian dilakukan secara purposive atau pertimbangan secara langsung dan sengaja karena dengan pertimbangan bahwa daerah yang dipilih memiliki potensi yang sangat besar sebagai 
wilayah sentra padi dari segi jumlah produksi, jumlah petani, potensi wilayah, mewakili daerah bagian barat-tengah-timur, dan daerah-daerah yang teraliri air irigasi. Daerah bagian timur dan tengah yang dialiri air irigasi dari Bendung Rentang adalah Kecamatan Sliyeg dan Kecamatan Lelea. Daerah bagian barat yang dialiri air irigasi dari Bendungan Jatiluhur adalah Kecamatan Gabuswetan. Pelaksanaan penelitian dilakukan dari bulan Februari sampai Agustus 2014.

\section{PENENTUAN HIERARKI KRITERIA DAN ALTERNATIF UPAYA PENGEMBANGAN AGRIBISNIS PADI}

Langkah-langkah menentukan hierarki kriteria dan alternatif upaya pengembangan agribisnis padi di Kabupaten Indramayu (Gambar 1) sebagai berikut:

1. Langkah awal pada penelitian ini dilakukan dengan wawancara pada 120 responden petani padi, instansi terkait khususnya Dinas Pertanian Tanaman Pangan dan Peternakan Kabupaten Indramayu dan Dinas Pengelolaan Sumber Daya Air Tambang dan Energi Kabupaten Indramayu untuk memperoleh permasalahan dan potensi yang ada pada agribisnis padi dan dikelompokkan pada sub sistem agribisnis padi sebagai kriteria.

2. Menghubungkan hasil wawancara tersebut dengan data sekunder dari Laporan Dinas Pertanian Tanaman Pangan dan Peternakan dan Laporan Dinas PSDA Tamben Kabupaten Indramayu. Kemudian dikelompokkan menjadi bagian di dalam kriteria sebagai alternatif-alternatif upaya pengembangan agribisnis padi.

3. Tahap selanjutnya, melakukan wawancara mendalam pada key person untuk mendapatkan potensi maupun permasalahan yang nyata di lapangan yang perlu diperbaiki ataupun dikembangkan pada agribisnis padi sebagai kriteria dan alternatif.

4. Kemudian hasil dari wawancara mendalam pada key person dilanjutkan dengan langkah penentuan kriteria dan alternatif dihubungkan dengan hasil wawancara pada responden petani padi dan hasil laporan dinas terkait sehingga terdapat hal-hal yang tidak diperlukan ataupun halhal yang dapat digabungkan. Hal ini terangkum pada Gambar 1, terdapat lima kriteria dan alternatif-alternatifnya sebagai hierarki upaya pengembangan agribisnis padi di Kabupaten Indramayu.

Lima Kriteria dan alternatif-alternatif upaya pengembangan agribisnis padi sebagai berikut : Pertama, Kriteria komitmen pemerintah daerah terdapat lima alternatif, yaitu: (1) konsistensi kebijakan pembangunan pertanian komoditas padi, (2) dukungan anggaran (pendanaan) bagi pembangunan pertanian komoditas padi, (3) pembuatan aturan di tingkat kabupaten berupa peraturan bupati untuk menghambat terjadinya alih fungsi lahan pertanian menjadi non pertanian, (4) penindakan tegas pada pelanggaran kebijakan pemerintah daerah, dan (5) pembuatan aturan di tingkat kabupaten berupa peraturan bupati seperti penyusunan peraturan pajak bumi dan bangunan pada lahan pertanian yang disesuaikan di daerah.

Kedua, Kriteria pemasaran terdapat lima alternatif, yaitu : (1) jaminan dan perlindungan harga petani melalui pengembangan lumbung desa modern (LDM), (2) peningkatan akses pasar bagi petani padi, (3) pembuatan badan usaha koperasi oleh kelompok tani padi untuk pemasaran padi, (4) melakukan kerjasama atau kemitraan oleh kelompok tani dengan pihak ketiga seperti swalayan (supermarket), dan (5) informasi pasar.

Ketiga, Kriteria sumber daya manusia (SDM) terdapat lima alternatif, yaitu : (1) peningkatan kualitas dan kuantitas petugas penyuluh di BKP3 (Badan Ketahanan Pangan Penyuluh Pertanian), (2) peningkatan kualitas dan kuantitas petani tanaman padi melalui pendidikan non formal, (3) peningkatan kapasitas aparat atau birokrat melalui diklat, (4) peningkatan kualitas dan kuantitas petugas pengamat hama dan penyakit tanaman (PHP) di UPTD (Unit Pelaksana 
Teknis Dinas), dan (5) peningkatan kualitas dan kuantitas petugas alat dan mesin pertanian di UPTD.

Keempat, Kriteria sarana dan prasarana terdapat sembilan alternatif, yaitu : (1) pengembangan dan pengelolaan sarana dan prasarana lumbung desa modern (LDM), (2) pengembangan sarana dan prasarana penangkaran benih, (3) pengembangan sarana dan prasarana irigasi, (4) pengembangan sarana dan prasarana pembuatan pupuk organik, (5) pengembangan sarana dan prasarana pestisida organik, (6) pengembangan sarana dan prasarana pengendalian OPT (organisme pengganggu tanaman), (7) pengembangan sarana dan prasarana alsintan (alat dan mesin pertanian), (8) pengembangan sarana dan prasarana pengolahan limbah padi dari jerami menjadi usaha pakan ternak sapi, dan (9) pengembangan sarana dan prasarana pengolahan limbah padi dari dedak dan sekam menjadi usaha pakan ternak unggas.

Kelima, Kriteria permodalan terdapat lima alternatif, yaitu : (1) bantuan modal dari Badan Usaha Milik Daerah (BUMD) seperti BWI (Badan Wiralodra Indramayu), (2) menumbuhkan koperasi simpan pinjam di kelompok tani, (3) subsidi bunga dari pemerintah seperti pupuk, Kredit Usaha Rakyat (KUR), Kredit Ketahanan Pangan dan
Energi (KKP-E), (4) kredit dari perbankan (BRI, BNI, dan lainnya), dan (5) pinjaman natura dari kios saprotan (sarana dan produksi tanaman).

\section{ANALISIS AHP}

\section{KONSEP ANALITYCAL HIERARCHY PROCESS (AHP)}

Analitycal Hierarchy Process (AHP) merupakan analisis yang menggunakan Expert Choice 9.0 dan didukung dengan wawancara mendalam pada key person (terpilih) sebagai sumber data untuk menentukan prioritas strategi. Menurut Susilowati (2008) bahwa Analytical Hierarchy Process (AHP) adalah suatu metode analisis untuk merumuskan suatu pengambilan keputusan/pemecahan persoalan atau strategi atau program berdasarkan prioritas kepentingan dan kebutuhan serta memasukan pertimbangan secara logis yang bergantung pada imajinasi, pengalaman, dan pengetahuan. AHP dapat dijadikan sebagai bukti secara kuantitatif prioritas maupun urutan dalam mengambil sebuah keputusan (karena biasanya hanya secara kualitatif saja). Skala yang digunakan tergantung dari pandangan responden.

Tujuan :

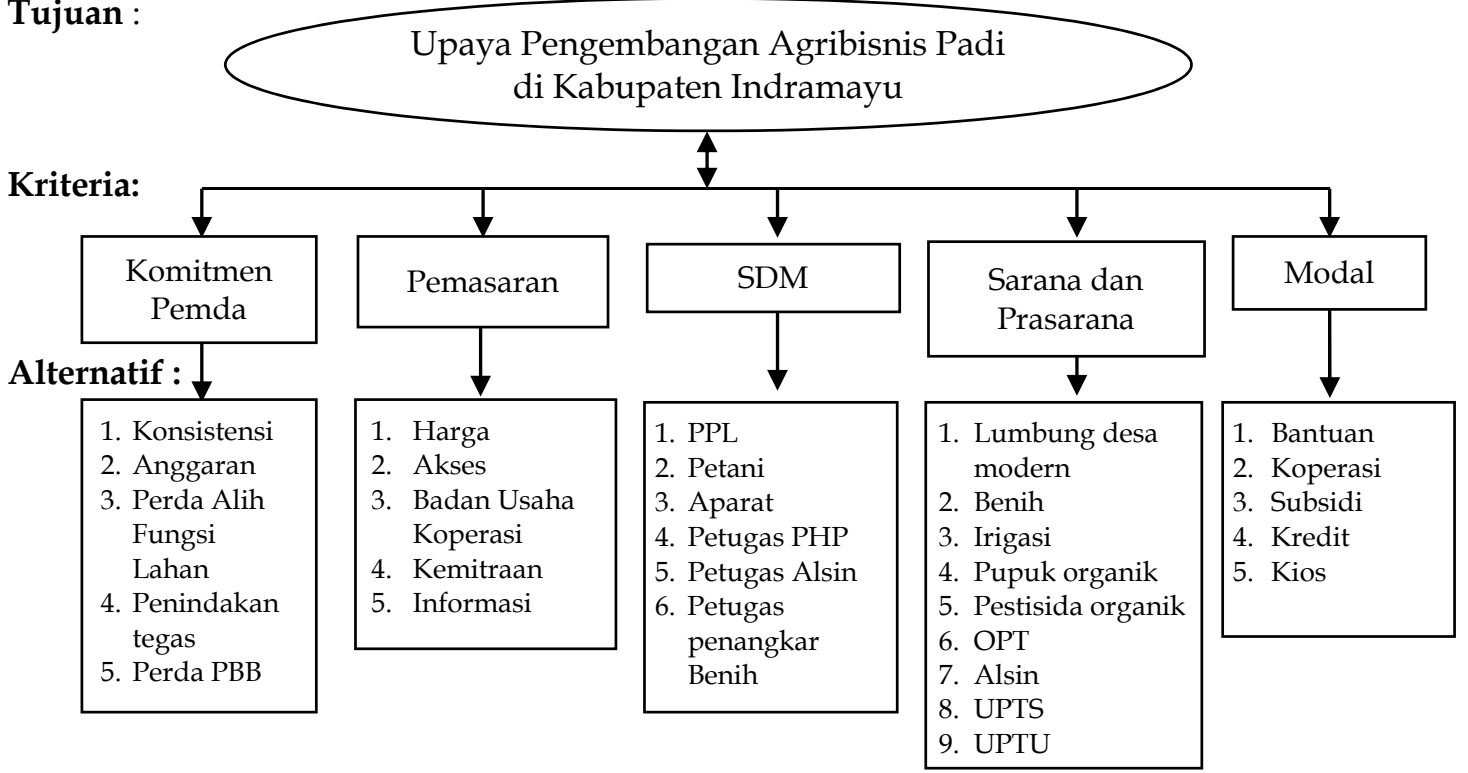

Gambar 1. Hierarki Kriteria dan Alternatif Upaya Pengembangan Agribisnis Padi di Kabupaten Indramayu 
Penentuan skala (tingkat urutan) atas persepsi responden mulai dari nilai bobot 1 sampai 9, dapat dilihat pada Tabel 3. Skala banding berpasangan digunakan dalam penyusunan AHP untuk menentukan susunan prioritas alternatif dan kriteria untuk mencapai sasaran pengembangan agribisnis padi di Kabupaten Indramayu yang tepat. Semua pertimbangan secara numerik dan validitasnya telah dievaluasi dengan suatu uji konsistensi maka dapat dijadikan sebagai pengambilan keputusan. Konsistensi sampai kadar tertentu dalam menetapkan prioritas untuk elemen-elemen dan aktivitas-aktivitas berkenaan dengan beberapa kriteria adalah perlu dilakukan untuk memperoleh hasilhasil sesuai dengan realitas (Saaty, 1993). Susilowati (2008) menyatakan bahwa penelitian terhadap kriteria dan alternatif dari hasil running dapat diterima dan dipercaya dengan melihat nilai rasio konsistensi. Nilai Inconsistenci Ratio (IR) harus lebih kecil atau maksimum sama dengan $10 \%$ (IR $\leq 0,1)$. Jika IR lebih besar dari $10 \%$ artinya pertimbangan tersebut dimungkinkan agak acak dan diperlukan perbaikan. Besarnya nilai IR diperoleh dari $100 \%$ dikurangi besarnya nilai rasio konsistensi (CR). Rumus CR sebagai berikut :

$\mathrm{CR}=\frac{C I}{R I}$

Keterangan :

CR: Consistency Ratio

\section{CI : Consistency Index \\ RI : Random Index}

Nilai Random Index yang dikeluarkan oleh Oarkridge Laboratory dapat dilihat pada Tabel 4. Responden ahli diperlukan dalam pengolahan data pada analisis AHP dapat digunakan hanya satu, akan tetapi dalam penerapannya untuk penilaian kriteria dan alternatif dilakukan dari beberapa ahli multidisipliner. Konsekuensinya bahwa pendapat dari beberapa ahli perlu di cek konsistensinya satu per satu. Pendapat yang konsisten digabungkan dengan menggunakan rata-rata geometrik (Saaty, 1993).

$X_{G}=\sqrt[n]{\pi^{n} X_{i}}$

Keterangan :

$\mathrm{X}_{G}$ : Rata-rata Geometri

$\mathrm{n}$ : Jumlah Responden

$\mathrm{x}_{\mathrm{i}}$ : Penilaian oleh responden ke-i

Pengolahan data selanjutnya menggunakan prosedur AHP dengan cara running melalui program Expert Choice Versi 9.0 dan urutan skala prioritas sesuai dengan bobot dari masing-masing alternatif serta besarnya konsistensi gabungan hasil running, dinyatakan bahwa jika nilai IR $\leq 0,1$, maka keputusan yang diambil oleh para key person dalam menentukan skala prioritas adalah konsisten, berarti prioritas tersebut dapat diimplementasikan sebagai kebijakan untuk mencapai tujuan.

Tabel 3. Sistem Dasar Urutan (Rangking) Analytical Hierarchy Process (AHP)

\begin{tabular}{|c|c|}
\hline Score & Definisi \\
\hline 1 & Kedua elemen sama penting \\
\hline 3 & Elemen yang satu sedikit lebih penting daripada elemen yang lain \\
\hline 5 & Elemen yang satu lebih penting dari elemen lainnya \\
\hline 7 & Satu elemen jelas lebih penting dari elemen lainnya \\
\hline 9 & Satu elemen mutlak lebih penting daripada elemen yang lainnya \\
\hline $2,4,6,8$ & Nilai-nilai antar dua nilai pertimbangan yang berdekatan \\
\hline Kebalikan & $\begin{array}{l}\text { Jika aktivitas i mendapat satu angka bila dibandingkan dengan aktivitas j, } \\
\text { maka j mempunyai nilai kebalikannya bila dibandingkan dengan } i \text {. }\end{array}$ \\
\hline
\end{tabular}

Sumber : Saaty, 1993.

Tabel 4. Nilai Random Index

\begin{tabular}{|l|l|l|l|l|l|l|l|l|l|l|l|l|l|}
$\mathbf{N}$ & $\mathbf{1}$ & $\mathbf{2}$ & $\mathbf{3}$ & $\mathbf{4}$ & $\mathbf{5}$ & $\mathbf{6}$ & $\mathbf{7}$ & $\mathbf{8}$ & $\mathbf{9}$ & $\mathbf{1 0}$ & $\mathbf{1 1}$ & 12 & 13 \\
\hline
\end{tabular}

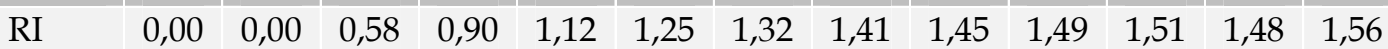

Sumber : Saaty, 1993. 


\section{HASIL DAN PEMBAHASAN}

\section{ANALISIS ANALITYCAL HIERARCHY PROCESS (AHP)}

Hasil dan pembahasan Analitycal Hierarchy Process (AHP) terdiri dari prioritas kriteria upaya pengembangan agribisnis padi, urutan prioritas alternatif-alternatif dari kriteria upaya pengembangan agribisnis padi, dan prioritas utama dari semua alternatif upaya pengembangan agribisnis padi.

\section{HASIL ANALISIS PADA KRITERIA}

Hasil analisis antar kriteria (pairwaise antar kriteria) upaya pengembangan agribisnis padi di Kabupaten Indramayu menggunakan Expert Choice versi 9.0 menunjukkan nilai IR (inconsistency ratio) sebesar 0,06 $\leq 0,1$ (Gambar 2), berarti keputusan yang diambil oleh responden key person dalam menentukan skala prioritas telah konsisten (Susilowati, 2008) sehingga dapat diterima dan diimplementasikan sebagai kebijakan untuk mencapai tujuan.

Gambar 2 menunjukkan bahwa skala prioritas kriteria, yaitu : (1) kriteria komitmen pemerintah daerah memiliki bobot 0,408 point, (2) kriteria pemasaran memiliki bobot 0,257 point, (3) kriteria sumber daya manusia memiliki bobot 0,164 point, (4) kriteria sarana dan prasarana memiliki bobot 0,098 point, dan (5) kriteria modal memiliki bobot 0,073 point. Hal ini berkaitan dengan pendapat Kartasapoetra, et al. (1989) bahwa keberhasilan agribisnis didasarkan pada implementasi kebijakan pemerintah yang sudah menjadi komitmen tertulis dalam peraturan perundangundangan tentang pengembangan pertanian atau agribisnis sehingga menjadi dorongan atau rangsangan bagi pelaku agribisnis, seperti petani atau pun pengusaha.

\section{ALTERNATIF UPAYA PENGEMBANGAN AGRIBISNIS PADI DI KABUPATEN INDRAMAYU PADA KRITERIA KOMITMEN PEMERINTAH DAERAH}

Hasil analisis terhadap alternatif (pairwaise antar alternatif) upaya pengembangan agribisnis padi di Kabupaten Indramayu pada kriteria

komitmen pemerintah daerah menggunakan Expert Choice versi 9.0 yaitu menunjukkan nilai IR (inconsistency ratio) sebesar 0,07 $\leq 0,1$ yang terlihat pada Gambar 3, berarti bahwa hasil analisis perbandingan antar alternatif pada kriteria komitmen pemerintah daerah sudah konsisten sehingga dapat diterima dan dapat diimplementasikan sebagai kebijakan untuk mencapai tujuan. Menurut Kartasapoetra, et al. (1989) bahwa keberhasilan agribisnis didasarkan pada implementasi kebijakan pemerintah yang sudah menjadi komitmen tertulis dalam peraturan perundangundangan tentang pengembangan pertanian atau agribisnis sehingga menjadi dorongan atau rangsangan bagi pelaku agribisnis, seperti petani atau pun pengusaha.

Gambar 3 menunjukkan bahwa skala prioritas alternatif pada kriteria komitmen pemerintah daerah terdiri dari : (1) Konsistensi kebijakan pemerintah daerah pada pembangunan pertanian komoditas padi memiliki bobot 0,324 point. (2) Dukungan anggaran dari pemerintah daerah Kabupaten Indramayu, memiliki bobot 0,264 point. Pemerintah Daerah Kabupaten Indramayu di dalam mengembangkan agribisnis padi harus memberikan kontribusi anggaran melalui APBD secara serius dan terus menerus karena tanpa adanya dukungan anggaran tentunya akan menghambat pengembangan agribisnis padi. (3) Pembuatan perda kabupaten untuk

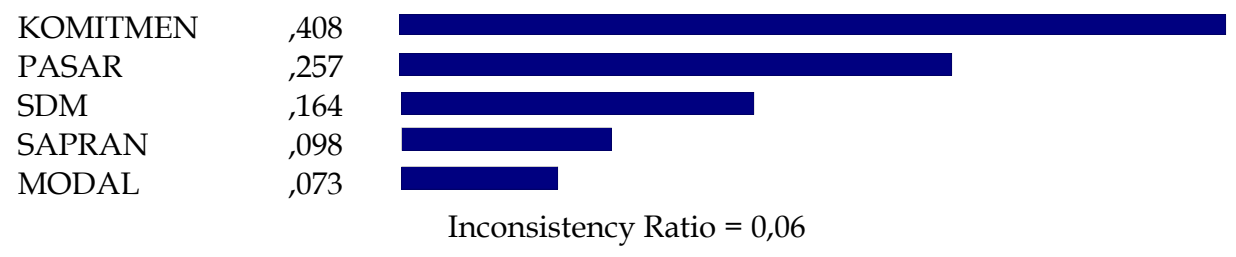

Gambar 2. Hasil Analisis Kriteria Upaya Pengembangan Agribisnis Padi di Kabupaten Indramayu 


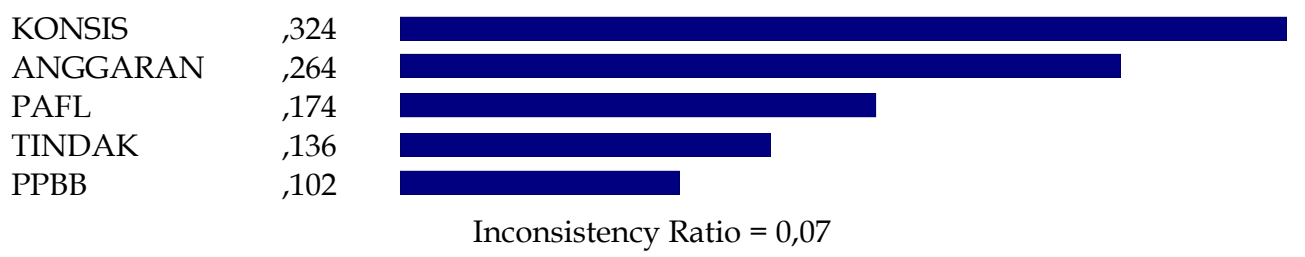

\section{Gambar 3. Hasil Analisis Alternatif Upaya Pengembangan Agribisnis Padi di Kabupaten Indramayu pada Kriteria Komitmen Pemerintah Daerah}

menghambat alih fungsi lahan pertanian ke non pertanian memiliki bobot 0,174 point. Mengingat lahan pertanian yang semakin berkurang karena perubahan fungsi menjadi lahan bukan pertanian seperti perumahan, pabrik, dan lainya maka pemda harus membuat aturan dari turunan UU No. 41 Tahun 2009 tentang Perlindungan Lahan Pertanian Pangan Berkelanjutan dan PP No.1 Tahun 2011 tentang Penetapan Perlindungan Alih Fungsi Lahan Pertanian Pangan Berkelanjutan. Iqbal (2007) menyatakan bahwa antisipasi terhadap konversi alih fungsi lahan sawah adalah pendataan lahan yang terkoordinir dan terpadu diikuti dengan kebijakan pengendalian konversi lahan yang segera diimplementasikan. (4) Penindakan tegas pada pelanggaran kebijakan pemda kabupaten memiliki bobot 0,136 point. Lemahnya implementasi peraturan yang sudah dibuat sehingga timbul pelanggaranpelanggaran, seperti Perda RTRW (Rencana Tata Ruang Wilayah) tentang aturan pemanfaatan ruang wilayah dilanggar oleh aparatnya sendiri misalnya dengan merubah lahan pertanian menjadi non pertanian (Iqbal, 2007). Penindakan tegas oleh aparat hukum harus dilakukan sehingga membuat efek jera bagi para pelanggar aturan hukum. (5) Pembuatan perda tentang pajak bumi dan bangunan (PBB) yang disesuaikan memiliki bobot 0,102 point. Pajak bumi dan bangunan terutama pada lahan pertanian perlu kejelasan yang disesuaikan dengan lokasi untuk memudahkan pemungutannya.

\section{ALTERNATIF UPAYA PENGEMBANGAN AGRIBISNIS PADI DI KABUPATEN INDRAMAYU PADA KRITERIA PEMASARAN}

Hasil analisis terhadap alternatif (pairwaise antar alternatif) upaya pengembangan agribisnis padi di Kabupaten Indramayu pada kriteria pemasaran menggunakan Expert Choice versi 9.0 menunjukkan nilai IR (inconsistency ratio) sebesar $0,08 \leq 0,1$ yang terlihat pada Gambar 4, berarti bahwa hasil analisis perbandingan antar alternatif pada kriteria pemasaran sudah konsisten sehingga dapat diterima dan dapat diimplementasikan sebagai kebijakan untuk mencapai tujuan.

Gambar 4 menunjukkan bahwa skala prioritas alternatif pada kriteria pemasaran terdiri dari : (1) Jaminan dan perlindungan harga padi melalui lumbung desa modern (LDM) memiliki bobot 0,382 point. Fungsi dari lumbung desa modern ini adalah jaminan harga padi, yaitu dengan cara menampung gabah pada saat panen raya karena harga sudah pasti rendah sehingga persediaan gabah di luaran akan berkurang menyebabkan harga akan stabil. Penjualan gabah setelah panen raya sehingga persediaan gabah di luaran akan meningkat dan harga gabah pun akan stabil atau tidak melonjak terlalu tinggi.

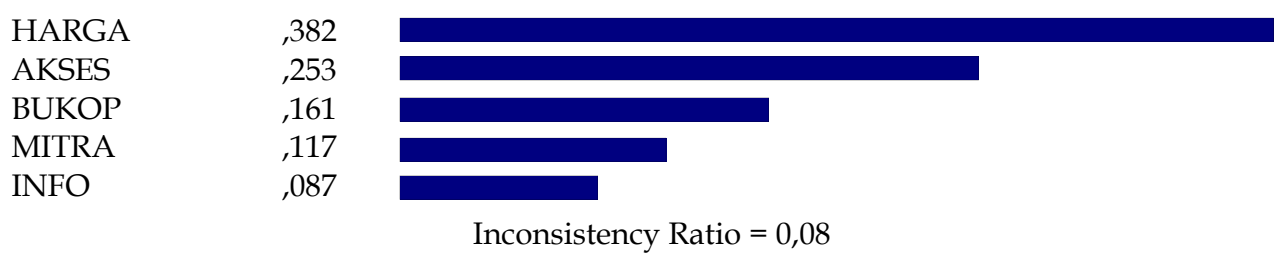

Gambar 4. Hasil Analisis Alternatif Upaya Pengembangan Agribisnis Padi Di Kabupaten Indramayu pada Kriteria Pemasaran 
(2) Peningkatan akses pasar pada pengembangan agribisnis padi memiliki bobot 0,253 point. Akses pasar memberikan keuntungan yang sangat besar bagi petani padi secara langsung karena dapat memutus rantai pasar. (3) Pemasaran padi melalui Badan Usaha Koperasi melalui Kelompok Tani Padi memiliki bobot 0,161 point. Koperasi merupakan badan usaha yang memiliki kekuatan hukum sehingga memiliki daya tawar yang cukup tinggi khususnya dalam hal penentuan harga pada pihak ketiga. (4) Melakukan kemitraan oleh kelompok tani dengan pihak ketiga seperti swalayan (supermarket) memiliki bobot 0,117 point. Purnaningsih dan Sugihen (2008) menyatakan bahwa keterlibatan petani dalam pola kemitraan terbukti terhadap perubahan penggunaan teknologi sehingga berpengaruh terhadap pendapatan petani. (5) Informasi pasar bagi petani padi memiliki bobot 0,87 point. Informasi pasar bagian yang tidak terpisahkan dalam memasarkan produk. Petani sangat diharapkan memperoleh informasi pasar terutama harga yang jelas, akurat, dan dapat dipertanggungjawabkan kebenarannya baik melalui sosialisasi peraturan pemerintah dengan harga pembelian pemerintah (HPP) maupun melalui media televisi, radio, ataupun internet untuk menghindari dari kenakalan para pedagang pengecer, pengumpul, atau tengkulak.

\section{ALTERNATIF UPAYA PENGEMBANGAN AGRIBISNIS PADI DI KABUPATEN INDRAMAYU PADA KRITERIA SUMBER DAYA MANUSIA (SDM)}

Hasil analisis terhadap alternatif (pairwaise antar alternatif) upaya pengembangan agribisnis padi di Kabupaten Indramayu pada kriteria sumber daya manusia menggunakan Expert Choice versi 9.0 menunjukkan nilai IR (inconsistency ratio) sebesar 0,06 $\leq 0,1$ yang terlihat pada Gambar 5, berarti bahwa hasil analisis perbandingan antar alternatif pada kriteria sumber daya manusia (SDM) sudah konsisten sehingga dapat diterima dan dapat diimplementasikan sebagai kebijakan untuk mencapai tujuan.

Gambar 5 menunjukkan bahwa skala prioritas alternatif pada kriteria sumber daya manusia terdiri dari : (1) Peningkatan kualitas dan kuantitas petugas penyuluh pertanian memiliki bobot 0,243 point. Petugas penyuluh pertanian di lapangan dituntut berkualitas terhadap pemahaman pertanian khususnya tanaman padi. Kabupaten Indramayu terjadi kekurangan tenaga penyuluh, yang dikarenakan setiap orang petugas membawahi 2-3 desa dalam satu kecamatan. Idealnya satu desa adalah satu orang petugas penyuluh lapangan agar lebih intensif memahami daerah binaan serta pembinaan terhadap petani atau kelompok tani terpenuhi dan berkesinambungan. Pendidikan tinggi dan rekruitmen penyuluh pertanian sesuai bidangnya. (2) Peningkatan kualitas dan kuantitas petani padi melalui pendidikan non formal memiliki bobot 0,210 point. Peningkatan kualitas khususnya petani di Kabupaten Indramayu melalui pendidikan non formal seperti SL-PHP, SL-Iklim, dan SLPP. (3) Peningkatan kapasitas bagi aparat atau birokrat melalui diklat memiliki bobot 0,174 point. Aparat atau birokrat dalam meningkatkan kapasitasnya untuk menentukan keputusan kebijakan yang diambil diperlukan pendidikan dan latihan (diklat) agar lebih mudah menyamakan persepsi dan

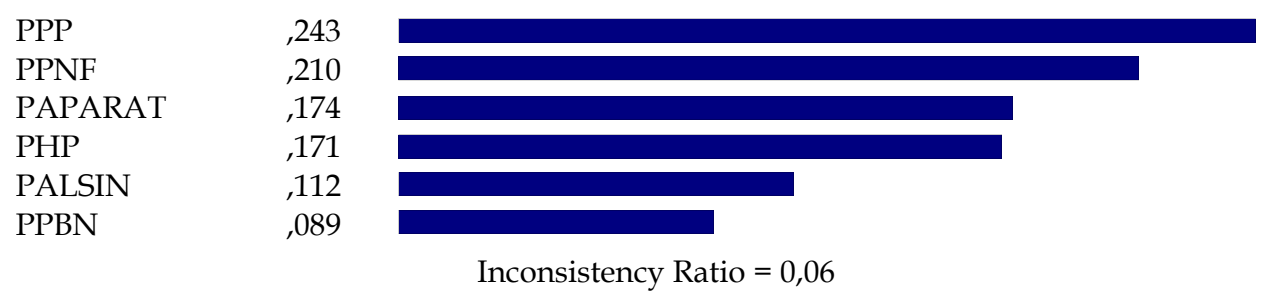

Gambar 5. Hasil Analisis Alternatif Upaya Pengembangan Agribisnis Padi di Kabupaten Indramayu pada Kriteria Sumber Daya Manusia (SDM) 


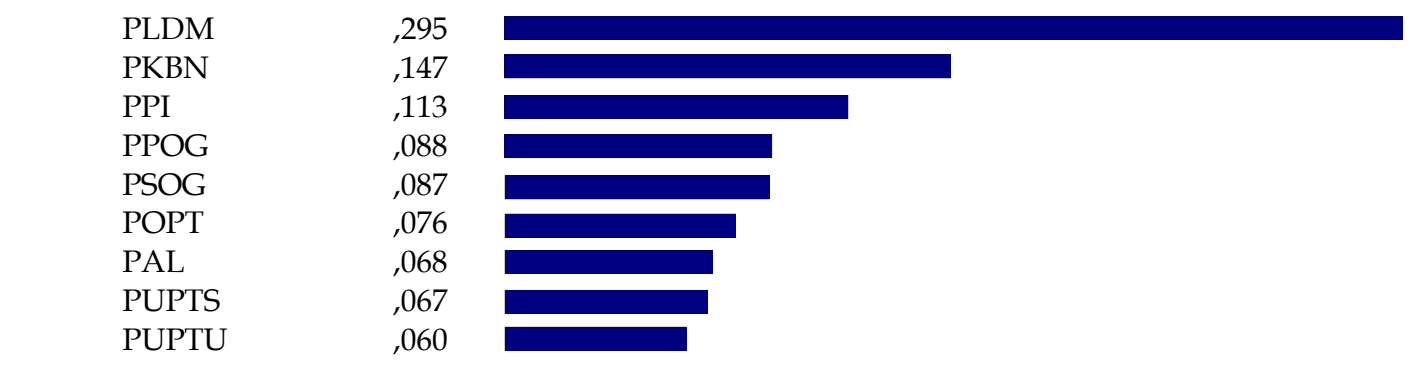

Inconsistency Ratio $=0,04$

\section{Gambar 6. Hasil Analisis Alternatif Upaya Pengembangan Agribisnis Padi di Kabupaten Indramayu pada Kriteria Sarana dan Prasarana}

pemahaman program, khususnya pengembangan agribisnis padi di Kabupaten Indramayu. (4) Peningkatan kualitas dan kuantitas bagi petugas pengamat hama dan penyakit tanaman memiliki bobot 0,171 point. Petugas pengamat hama dan penyakit tanaman di Kabupaten Indramayu sangat kurang karena seorang petugas membawahi 2 kecamatan (20-25 desa), tentunya kondisi ini akan menurunkan kinerja petugas karena luasnya lahan yang diamati sehingga penanganan terhadap penyerangan hama dan penyakit tanaman padi sering terlambat. Perlu rekruitmen pegawai sesuai bidangnya dan perlunya pelatihan pada pegawai yang sudah ada. (5) Peningkatan kualitas dan kuantitas petugas alsintan (alat dan mesin pertanian) memiliki bobot 0,112 point. Peningkatan kualitas produk diperlukan peralatan yang lebih baik atau sesuai dengan kondisi wilayah sehingga efisien tenaga, waktu, dan biaya dengan tenaga profesional di bidang alat dan mesin pertanian tersebut untuk mencetaknya. Pendidikan tinggi atau pelatihan bagi petugas alsintan sangat diperlukan baik di dalam negeri maupun di luar negeri mengingat teknologi berkembang cepat serta dilakukan perekrutan pegawai sesuai bidangnya. (6) Peningkatan kualitas dan kuantitas petugas penangkar benih dengan bobot 0,089 point. Petugas penangkar benih dapat diperoleh dari rekruitmen pemerintah daerah dan petani yang dijadikan sebagai mitra pemerintah di setiap kecamatan.

\section{ALTERNATIF UPAYA PENGEMBANGAN PADI DI KABUPATEN INDRAMAYU PADA KRITERIA SARANA DAN PRASARANA}

Hasil analisis terhadap alternatif (pairwaise antar alternatif) upaya pengembangan agribisnis padi di Kabupaten Indramayu pada kriteria sarana dan prasarana menggunakan Expert Choice versi 9.0 menunjukkan nilai IR (inconsistency ratio) sebesar 0,04 $\leq 0,1$ (Gambar 6). Hal ini berarti bahwa hasil analisis perbandingan antar alternatif pada kriteria sarana dan prasarana sudah konsisten sehingga dapat diterima dan dapat diimplemetasikan sebagai kebijakan untuk mencapai tujuan.

Gambar 6 menunjukkan bahwa skala prioritas alternatif pada kriteria sarana dan prasarana terdiri dari : (1) Pengembangan sarana dan prasarana pembuatan lumbung desa modern memiliki bobot 0,295 point. Lumbung desa modern adalah salah satu wadah yang dapat menstabikan harga gabah sehingga diperlukan sarana dan prasarananya di setiap desa. (2) Pengembangan sarana dan prasarana penangkaran benih padi memiliki bobot 0,147 point. Benih memegang kendali pada kualitas gabah yang dihasilkan. Penangkaran benih sangat diperlukan di Kabupaten Indramayu yang tersebar di setiap kecamatan untuk menutupi kekurangan dan dapat dijual jika berlebih. Petani Indramayu hampir 75 persen menggunakan benih dari PT. Sang Hyang Sri atau dari bantuan pemerintah yang terkadang datangnya terlambat sehingga kualitas benih telah menurun. Minimal satu kecamatan membuka 
lahan 50 ha untuk benih padi sehingga dalam 31 kecamatan terdapat 1.550 ha $(1,35 \%$ dari total luas lahan padi $=115.00$ ha). (3) Pengembangan sarana dan prasarana pengelolaan irigasi memiliki bobot 0,113 point. Irigasi merupakan sumber air bagi tanaman padi yang sangat dibutuhkan dalam pertumbuhan sehingga irigasi sangat dibutuhkan baik dalam pengembangan dan pengelolaan sarana dan prasarana agar air irigasi tetap tersedia dan tersalur secara merata. (4) Pengembangan sarana dan prasarana pembuatan pupuk organik memiliki bobot 0,088 point. Produktivitas lahan padi yang semakin menurun dikarenakan terus-menerus diberikan pupuk kimia anorganik dan tidak diimbangi dengan pemberian bahan organik, seperti pupuk organik ataupun kompos. Bahan organik yang digunakan dapat berasal dari limbah padi yaitu jerami diolah menjadi kompos atau pupuk organik. Menurut Hardjowigeno (2007) bahwa tanah yang kurang bahan organik menyebabkan unsur hara yang diberikan seperti pupuk anorganik (Urea, $\mathrm{KCl}, \mathrm{TSP}$ ) tidak cukup tersedia di dalam tanah untuk akar tanaman karena diikat kuat oleh tanah. (5) Pengembangan sarana dan prasarana pembuatan pestisida organik memiliki bobot 0,087 point. Dinas Pertanian dan Peternakan Kabupaten Indramayu secara umum tidak memberikan rekomendasi pestisida anorganik dalam jumlah tertentu karena dampak dari pestisida anorganik tidak saja pada kesehatan petani tetapi berdampak pada pencemaran lingkungan air, tanah, dan udara, dan sangat baik jika diberikan pestisida organik. (6) Pengembangan sarana dan prasarana pengendalian organisme pengganggu tanaman (OPT) memiliki bobot 0,076 point. Sarana dan prasarana untuk OPT seperti perangkap hama tikus dan alat penyemprotan serta pembuatan alat semprot khusus untuk pestisida organik yang disesuaikan. (7) Pengembangan sarana dan prasarana alat dan mesin pertanian memiliki bobot 0,068 point. Alat dan mesin pertanian khususnya padi sangat banyak sekali buatan luar negeri, yang tentunya belum cocok untuk Kabupaten Indramayu sehingga diperlukan alat dan mesin yang disesuaikan kondisi daerah agar efisien dan efektif dari segi tenaga kerja, waktu, dan biaya. (8) Pengembangan sarana dan prasarana usaha pakan ternak sapi memiliki bobot 0,067 point. Limbah dari tanaman padi seperti jerami dalam pemanfaatannya belum dioptimalkan, penggunaannya hanya sebatas dibakar untuk dikembalikan ke tanah. Pengolahan limbah jerami ini dapat menjadi bahan pakan ternak sapi. (9) Pengembangan sarana dan prasarana usaha pakan ternak unggas memiliki bobot 0,060 point. Limbah dari gabah berupa dedak dan sekam dapat dijadikan bahan pakan ternak. Perlunya pembuatan sarana dan prasarana pakan ternak unggas dimaksudkan untuk memberikan nilai tambah bagi petani sehingga menambah pendapatan petani, kelompok tani, dan menjadi pendapatan daerah dengan produksi skala besar.

\section{ALTERNATIF UPAYA PENGEMBANGAN AGRIBISNIS PADI DI KABUPATEN INDRAMAYU PADA KRITERIA PERMODALAN}

Hasil analisis terhadap alternatif (pairwaise antar alternatif) upaya pengembangan agribisnis padi di Kabupaten Indramayu pada kriteria permodalan menggunakan Expert Choice versi 9.0 menunjukkan nilai IR (inconsistency ratio) sebesar 0,04 $\leq 0,1$ yang terlihat pada Gambar 7, berarti bahwa hasil analisis perbandingan antar alternatif pada kriteria permodalan sudah konsisten sehingga dapat diterima dan dapat diimplementasikan sebagai kebijakan untuk mencapai tujuan. Gambar 7 menunjukkan bahwa skala prioritas alternatif pada kriteria permodalan terdiri dari : (1) Bantuan modal dari Badan Usaha Milik Daerah (BUMD) memiliki bobot 0,423 point. Bantuan modal untuk pengembangan agribisnis padi di Kabupaten Indramayu diharapkan dari BUMD seperti Badan Wiralodra Indramayu (BWI). BWI bekerjasama dengan PT. Pupuk Kujang dan PT. Gresik dalam pengelolaan subsidi dan pendistribusian pupuk ke petani melalui Dinas Pertanian dan Peternakan Kabupaten 


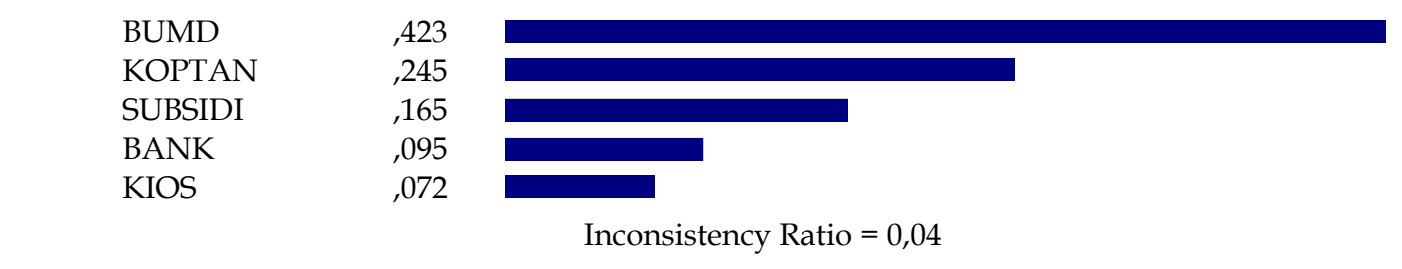

\section{Gambar 7. Hasil Analisis Alternatif Upaya Pengembangan Agribisnis Padi di Kabupaten Indramayu pada Kriteria Permodalan}

Indramayu. PT. Gresik mendistribusikan pupuk anorganik, seperti NPK Phonska (unsur $15 \% \mathrm{~N}, 15 \% \mathrm{P}_{2} \mathrm{O}_{5}, 15 \% \mathrm{~K}_{2} \mathrm{O}$, dan $10 \% \mathrm{~S}$ ) dan Urea (unsur $46 \% \mathrm{~N}$ ) serta pupuk organik, seperti Super Petroganik (unsur 12,30\% COrganik, 15,19\% C/N Rasio, 8,16\% Kadar Air, dan $\mathrm{pH}=8,03)$. PT. Kujang mendistribusikan pupuk NPK Kujang. Pemerintah Daerah Kabupaten Indramayu merencanakan BWI bekerjasama dengan pihak ketiga untuk memperoleh modal tambahan sebagai pembeli padi secara langsung pada petani saat panen raya. Bantuan langsung benih sangat dibutuhkan. (2) Menumbuhkan koperasi simpan pinjam di kelompok tani memiliki bobot 0,245 point. Koperasi simpan pinjam bertujuan menumbuhkan kemandirian modal pada anggotanya dari pihak manapun, seperti pengolahan lahan dan kebutuhan sarana produksi pertanian, seperti benih, pupuk, dan obat-obatan pada waktu yang tepat. (3) Subsidi bunga kredit dari pemerintah seperti Kredit Ketahanan Pangan dan Energi (KKP-E) dan Kredit Usaha Rakyat (KUR) memiliki bobot 0,165 point. Ratnawati (2009) menyatakan bahwa upaya pemerintah dalam mengatasi pembiayan sektor pertanian melalui APBN (Anggaran Pendapatan Belanja Negara) sejak tahun 2007 sampai sekarang, yaitu memberikan subsidi bunga kredit kepada petani, kelompok tani maupun koperasi melalui bank pemerintah seperti BNI, BRI, dan Bank Mandiri berupa KKP-E, KUR. (4) Kredit dari perbankan memiliki bobot 0,095 point. Kredit dari perbankan sangat diperlukan sekali oleh petani sebagai modal tanam, hanya diperlukan aspek kualitas persyaratan seperti agunan (jaminan) berupa sertifikat tanah/bangunan yang masih sulit untuk pelaku usaha tani membuktikannya (Syukur et al., 2002), suku bunga yang cukup tinggi berkisar 18-22 persen, dan pembayarannya setiap bulan. (5) Pinjaman natura dari kios sarana produksi pertanian memiliki bobot 0,072 point. Para petani yang tidak memiliki modal awal dalam mengolah padi biasanya mereka meminjam dalam bentuk natura (barang) di kios pertanian yang akan dibayar setelah panen, seperti pupuk dan obat-obatan pemberantas hama dan penyakit tanaman. Hal ini sangat membantu sekali bagi petani yang tidak memilik modal awal, tetapi bunga pinjamannya cukup besar berkisar 25-30 persen jika dibandingkan dengan kredit di bank. Kios Saprotan diharapkan memberikan bunga pinjaman natura tidak terlalu tinggi kepada petani padi.

\section{SEMUA ALTERNATIF UPAYA PENGEMBANGAN AGRIBISNIS PADI DI KABUPATEN INDRAMAYU PADA SEMUA KRITERIA}

Hasil analisis gabungan dari semua alternatif (synthesis antar semua alternatif) upaya pengembangan agribisnis padi di Kabupaten Indramayu pada semua kriteria menggunakan Expert Choice versi 9.0 menunjukkan nilai IR (inconsistency ratio) sebesar $0,06 \leq 0,1$ yang terlihat pada Gambar 8, berarti bahwa hasil analisis perbandingan lima prioritas alternatif pada semua kriteria sudah konsisten sehingga dapat diterima dan dapat diimplementasikan sebagai kebijakan untuk mencapai tujuan.

Gambar 8 menunjukkan adanya lima prioritas alternatif pada semua kriteria yang ada sebagai formula upaya pengembangan agribisnis padi di Kabupaten Indramayu yang harus diperhatikan dan dilakukan sebagai kebijakan pemerintah daerah agar dapat memenuhi program swasembada berkelanjutan dengan terjadinya peningkatan 
produksi padi dan pendapatan di tingkat petani Kabupaten Indramayu, yaitu : (1) Konsistensi kebijakan pemerintah daerah pada pembangunan pertanian komoditas padi memiliki bobot 0,412 point. Keteguhan hati dari niat pemerintah daerah pada kebijakan pembangunan pertanian padi adalah modal utama dari semua faktor yang ada untuk mencapai tujuan. Menurut Kartasapoetra, et al. (1989) bahwa keberhasilan agribisnis didasarkan pada implementasi kebijakan pemerintah yang sudah menjadi komitmen tertulis dalam peraturan perundang-undangan tentang pengembangan pertanian atau agribisnis sehingga dapat menjadi dorongan atau rangsangan bagi pelaku agribisnis, seperti petani atau pun pengusaha. (2) Jaminan dan perlindungan harga padi melalui lumbung desa modern (LDM) memiliki bobot 0,261 point. Fungsi lumbung desa modern adalah jaminan harga padi, yaitu dengan cara menampung sebagian besar gabah pada saat panen raya dan menjual sebagian besar pada musim tanam. Hal ini dikarenakan saat panen raya jumlah gabah melimpah maka harga akan turun, agar harga tidak turun maka sebagian jumlah gabah ditampung di lumbuh desa modern maka jumlah gabah berkurang di pasar sehingga harga gabah akan stabil atau tidak terlalu rendah. Penjualan gabah dilakukan setelah panen raya karena jumlah di pasaran sudah berkurang atau sedikit sehingga jumlah gabah di pasaran akan meningkat dan harga gabah pun akan stabil atau naik dengan lonjakan tidak terlalu tinggi. Hal ini disebabkan petani menjual padi dalam bentuk gabah di rumah melalui tengkulak sebanyak 109 responden $(90,83 \%)$, di lahan sebanyak 2 responden $(1,67 \%), 5$ responden $(4,17 \%)$ di penggilingan, dan 4 responden $(3,33 \%)$ dalam bentuk beras di pasar. Hal ini disebabkan peranan pemerintah melalui Bulog tidak berfungsi karena Bulog membeli gabah petani di bawah harga tengkulak yaitu $\mathrm{Rp}$ 3.300,- per kg GKP sedangkan tengkulak Rp 3.700,- sampai Rp 4.500,- per kg GKP dan Bulog membayar tidak tunai sedangkan tengkulak membeli tunai pada petani. Oleh karena itu disarankan untuk membangkitkan kembali fungsi lumbung desa modern sehingga harga gabah dapat terjamin. (3) Peningkatan kualitas dan kuantitas petugas penyuluh pertanian memiliki bobot 0,140 point. Petugas penyuluh pertanian dituntut berkualitas terhadap pemahaman pertanian, khususnya tanaman padi. Permasalahan yang jelas adalah kekurangan tenaga penyuluh dikarenakan setiap orang petugas membawahi 2-3 desa dalam satu kecamatan di Kabupaten Indramayu. Idealnya satu desa adalah satu orang penyuluh pertanian agar lebih intensif dalam memahami daerah binaan, pembinaan pada petani atau kelompok tani, dan berkesinambungan. Perlunya pendidikan tinggi dan rekruitmen pegawai harus sesuai bidang dan keahliannnya. (4) Pengembangan sarana dan prasarana pembuatan lumbung desa modern memiliki bobot 0,106 point. Lumbung desa modern adalah wadah untuk menyimpan gabah sementara dengan memperhatikan kualitas agar tidak turun dan sebagai salah satu wadah yang dapat menstabilkan harga gabah. Pengembangan sarana dan prasarana lumbung desa modern ini sangat dibutuhkan di setiap desa agar memudahkan petani dan sewaktu-waktu dapat diambil dan dijual untuk modal.

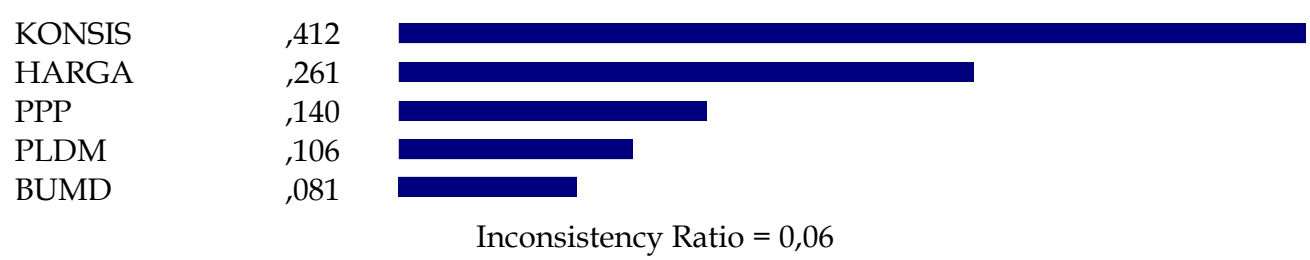
Gambar 8. Lima Prioritas Alternatif Sebagai Formula Upaya Pengembangan
Agribisnis Padi di Kabupaten Indramayu 
Kabupaten Indramayu memiliki sebuah resi gudang sebagai penyimpanan gabah atau beras di Kecamatan Tukdana tetapi tidak sesuai dengan kebutuhan petani karena jaraknya cukup jauh sehingga memerlukan biaya transportasi angkut dan perjalanan, memerlukan biaya-biaya seperti biaya simpan, asuransi yang memberatkan petani, dan lain-lain. Melihat hal ini maka undangundang tentang resi gudang perlu ditinjau ulang. (5) Bantuan modal dari Badan Usaha Milik Daerah (BUMD) memiliki bobot 0,81 point. Permodalan bagi petani padi dalam usahataninya masih mengalami kendala, sekitar 90 responden petani $(75 \%)$ mengalami kendala permodalan dan hanya 30 responden petani $(25 \%)$ yang tidak mengalami kendala permodalan. Hal ini disebabkan rendahnya akses petani ke bank karena sulitnya pernyaratan dan adanya agunan sebanyak 37 responden petani $(30,83 \%)$, bunga yang tinggi sebanyak 14 responden petani $(11,67 \%)$ sehingga kurang lebih 73 responden petani $(60,83 \%)$ tidak pernah pinjam modal ke bank selebihnya dari dana sendiri atau pinjam kepada kios dalam bentuk natura. Bantuan modal untuk pengembangan agribisnis padi di Kabupaten Indramayu diharapkan dari Badan Usaha Milik Daerah (BUMD) seperti Badan Wiralodra Indramayu (BWI). Selama ini, kegiatan BWI adalah bekerjasama dengan PT. Pupuk Kujang dan PT. Gresik dalam pengelolaan subsidi dan pendistribusian pupuk ke petani melalui Dinas Pertanian dan Peternakan Kabupaten Indramayu. PT. Gresik mendistribusikan pupuk anorganik, seperti NPK Phonska (unsur 15\%N, $15 \% \mathrm{P}_{2} \mathrm{O}_{5}$, $15 \% \mathrm{~K}_{2} \mathrm{O}$, dan $10 \% \mathrm{~S}$ ) dan Urea (unsur $46 \% \mathrm{~N}$ ) serta pupuk organik, seperti Super Petroganik (unsur 12,30\%C-Organik, 15,19\% C/N Rasio, 8,16\% Kadar Air, dan $\mathrm{pH}=8,03)$. PT. Kujang mendistribusikan pupuk NPK Kujang. Pemerintah Daerah Kabupaten Indramayu merencanakan BWI bekerjasama dengan pihak ketiga untuk memperoleh modal tambahan sebagai pembeli padi secara langsung pada petani saat panen raya.

Prioritas utama alternatif upaya pengembangan agribisnis padi di Kabupaten Indra- mayu yang tepat dari kelima prioritas yang ada adalah konsistensi kebijakan pembangunan pertanian komoditas padi pada pemerintah daerah dengan memiliki bobot tertinggi sebesar 0,412 point.

\section{SIMPULAN DAN SARAN SIMPULAN}

Hasil Analysis Hierarchy Process (AHP) merumuskan lima prioritas alternatif sebagai formula dan rekomendasi Pemerintah Daerah Kabupaten Indramayu dalam upaya pengembangan agribisnis padi, yaitu: konsistensi kebijakan pembangunan pertanian komoditas padi pada pemerintah daerah, jaminan dan perlindungan harga padi melalui lumbung desa modern, peningkatan kualitas dan kuantitas petugas penyuluh pertanian, pengembangan sarana dan prasarana lumbung desa modern, dan bantuan modal dari Badan Usaha Milik Daerah. Prioritas utama alternatif upaya pengembangan agribisnis padi di Kabupaten Indramayu adalah konsistensi kebijakan pemerintah daerah pada pembangunan pertanian komoditas padi.

\section{SARAN}

Dukungan dan peran serta pemerintah daerah Kabupaten Indramayu sebagai regulator, motivator, dan fasilitator sangat diharapkan implementasinya pada upaya pengembangan agribisnis padi dalam pembangunan pertanian agar dapat mewujudkan swasembada beras berkelanjutan.

\section{DAFTAR PUSTAKA}

BPS Jawa Barat. 2010. Jawa Barat Dalam Angka. Badan Pusat Statistik dan Bappeda Provinsi Jawa Barat.

BPS Jawa Barat. 2011. Jawa Barat Dalam Angka. Badan Pusat Statistik dan Bappeda Provinsi Jawa Barat. 
BPS Jawa Barat. 2012. Jawa Barat Dalam Angka. Badan Pusat Statistik dan Bappeda Provinsi Jawa Barat.

BPS Jawa Barat. 2013. Jawa Barat Dalam Angka. Badan Pusat Statistik dan Bappeda Provinsi Jawa Barat.

Dinas Pertanian dan Peternakan. 2011. Laporan Tahunan. Kabupaten Indramayu.

Dinas Pertanian dan Peternakan. 2012. Laporan Tahunan. Kabupaten Indramayu.

Dinas Pertanian dan Peternakan. 2013. Laporan Tahunan. Kabupaten Indramayu.

Hardjowigeno, S. 2007. Ilmu Tanah. Cetakan Keenam. Penerbit CV. Akademika Pressindo. Jakarta.

Iqbal, M. 2007. Fenomena dan Strategi Kebijakan Pemerintah Daerah dalam Pengendalian Konversi Lahan Sawah di Provinsi Bali dan Nusa Tenggara Barat. Pusat Analisis Sosial Ekonomi dan Kebijakan Pertanian. Desember 2007. Volume 5. Nomor 4. Hal: 287-303.

Kartasapoetra, G., R.G. Kartasapoetra, dan A.G. Kartasapoetra. 1989. Manajemen Pertanian (Agribisnis). Cetakan Kedua. Penerbit PT. Bina Aksara. Jakarta.

Nataprawira. 2006. Strategi Pengembangan Pertanian Padi (Oryza sativa. L) Organik di Kabupaten Bandung. Tesis Program Magister Sosial Ekonomi. Universitas Padjadjaran Bandung.

Nazir, M. 1983. Metode Penelitian. Cetakan Ketiga. Ghalia Indonesia. Jakarta.

Peraturan Menteri Pertanian No.15/ Permentan/Rc.110/1/2010 Tentang Rencana Strategis Kementerian Pertanian Tahun 2010-2014.

Peraturan Pemerintah No. 68 Tahun 2002 Tentang Ketahanan Pangan.

Peraturan Pemerintah No.1 Tahun 2011 Tentang Penetapan Perlindungan Alih Fungsi Lahan.
Purnaningsih, N. dan B. G. Sugihen. 2008. Manfaat Keterlibatan Petani Dalam Pola Kemitraan Agribisnis Sayuran di Jawa Barat. Jurnal Penyuluhan : September 2008, Vol. 4. No.2. ISSN : 1858-2664.

Ratnawati, A. 2009. Mencari Alternatif Pembiayaan Pertanian. Makalah disampaikan pada Round Table Discussion: Mencari Alternatif Pembiayaan Pertanian. Kerjasama Kementerian Koordinator Bidang Perekonomian dan Departemen Agribisnis, FEM-IPB. Jakarta.

Saaty, T. L. 1993. Pengambilan Keputusan Bagi Para Pemimpin (Terjemahan : Liana Setiono). PT. Pustaka Binaman Pressindo. Jakarta.

Suherman, A. 2013. Kehidupan Petani Pasca Konversi Lahan Sawah Beririgasi di Kabupaten Indramayu. Disertasi Program Doktor Ilmu Pertanian. Universitas Padjadjaran Bandung.

Susilowati, I. 2008. Pengambilan Keputusan Melalui Analitical Hierarchy Process (AHP) Dengan Paket Program Expert Choice Versi 9.0. Fakultas Ekonomi Universitas Diponegoro. Semarang.

Syukur, M., E. L. Hastuti, Soentoro, A. Supriatna, Supandi, Sumedi, dan B.W.D. Wicaksono. 2002. Kajian Pembiayaan Pertanian Mendukung Pengembangan Agribisnis dan Agroindustri di Pedesaan. Pusat Penelitian dan Pengembangan Sosial Ekonomi Pertanian. Badan Penelitian dan Pengembangan Pertanian.

Undang-Undang Nomor 17 Tahun 2007 Tentang Rencana Pembangunan Jangka Panjang (RPJPN) 2005 - 2025.

Undang-Undang nomor 41 Tahun 2009 Tentang Perlindungan Lahan Pertanian Berkelanjutan. 
